UDC 622:552.578.2.061.33

Article / Статья

(C) PNRPU / ПНИПУ, 2020

\title{
Prediction of Oil and Gas Occurrence in the Southern Part of Perm Krai Based on Regional 3D Modeling
}

\section{Aleksey L. Yuzhakov, Ivan S. Putilov}

PermNIPIneft branch of LUKOIL-Engineering LLC in Perm (3a Permskaya st., Perm, 614015, Russian Federation)

\section{Прогнозирование нефтегазоносности южной части Пермского края с использованием регионального трехмерного моделирования}

\section{А.Л. Южаков, И.С. Путилов}

Филиал ООО «ЛУКОЙЛ-Инжиниринг» «ПермНИПИнефть» в г. Перми (Россия, 614015, г. Пермь, ул. Пермская, За)

\section{Received / Получена: 08.04.2020. Accepted / Принята: 25.08.2020. Published / Опубликована: 26.10.2020}

Keywords:

Regional modeling, structure, trap, oil and gas occurrence, field, hydrocarbons, step-by-step linear discriminant analysis, reflecting horizon, seismic survey, machine learning, organic matter, geochemistry, hydrogeology, prediction, probability model, Pearson criterion.

Ключевые слова: региональное моделирование, структура, ловушка, нефтегазоносность, месторождение, углеводороды, пошаговый линейный дискриминантный анализ, отражающий горизонт, сейсморазведка, машинное обучение, органическое вещество, геохимия, гидрогеология, прогнозирование, вероятностная модель, критерий Пирсона.
The territory of the southern part of Perm Krai is well studied in terms of oil and gas prospecting. About 150 oil and gas fields have been discovered there, over 7000 deep wells have been drilled, and 3D seismic surveys have been completed on the area exceeding $5000 \mathrm{~km}^{2}$. The state of exploration of the territory allows us to have an immense array of geologic information, which can be used to search and predict oil and gas occurrence in structures that remain left out or that have not been studied yet. The research area was limited by the confines of Perm Krai in the south, west, and east and by a conventional line in the north along the boundary of the completed seismic surveys.

To study the territory based on the reflecting horizon surface of Perm Krai, a 3D geological model has been built within IRAPRMS software system. The model calculates a regional, a zonal and local constituents of the reflecting horizon of Perm Krai. The local constituent allowed us to single out structures divided into three categories: structures of ascertained oil and gas occurrence, structures that do not contain oil and gas (empty), and structures for which a prediction is needed. In the model, structural parameters representing a trap potential for the accumulation and retention of hydrocarbons were calculated. Moreover, geochemical parameters showing a generation potential and a migration constituent, as well as hydrogeological parameters as indirect data to determine the saturation of structures with hydrocarbons, were downloaded into the model. The obtained data about the importance of each parameter for all structures allowed us to generate a single database and predict oil and gas occurrence by the machine learning method, i.e. through the step-bystep linear discriminant analysis. Based on the results of the linear discriminant analysis, 138 predicted structures were arranged in groups in accordance with degrees of their potential. By applying the built individual probability models, a map of the regional probability of structures' saturation with hydrocarbons was obtained; this map served as a basis and amendment of oil and gas geological zoning boundaries of the southern part of Perm Krai.

Территория южной части Пермского края характеризуется большой нефтегазогеологической изученностью, здесь открыто порядка 150 месторождений нефти и газа, пробурено более 7000 глубоких скважин, проведены сейсморазведочные работы в формате $3 \mathrm{D}$ на площади более $5000 \mathrm{kM}^{2}$. Изученность территории позволяет получить огромный массив геологической информации, который можно использовать для поиска и прогноза нефтегазоносности пропущенных или не исследованных ранее структур. Область исследования была ограничена с юга, запада и востока границами Пермского края, а с севера - условной линией по границе проведенных сейсморазведочных работ.

Для изучения территории на основании поверхности отражающего горизонта Пермского края была построена трехмерная геологическая модель в программном комплексе IRAP RMS. В модели рассчитаны региональная, зональная и локальная составляющие отражающего горизонта Пермского края. Локальная составляющая позволила выделить структуры, которые поделены на три категории: структуры с установленной нефтегазоносностью, структуры, не содержащие нефть и газ (пустые), и структуры, по которым необходимо выполнить прогноз. В модели были рассчитаны структурные параметры, отражающие потенциал ловушки для аккумуляции и сохранения залежей углеводородов. Также в модель были загружены геохимические параметры, отражающие генерационный потенциал и миграционную составляющую, и гидрогеологические параметры как косвенные при определении насыщения структур УВ. Полученные сведения о значении каждого параметра по всем структурам позволили собрать в единую базу данных и провести прогноз нефтегазоносности структур методом машинного обучения - пошаговым линейным дискриминантным анализом. По итогам пошагового линейного дискриминантного анализа 138 прогнозируемых структур были отранжированы по степени их перспективности. На основании построенных индивидуальных вероятностных моделей получена карта региональной вероятности насыщения структур углеводородами, которая послужила основой для уточнения границ нефтегазогеологического районирования территории южной части Пермского края.

Aleksey L. Yuzhakov - Junior Researcher of the Petrophysical Modeling Department (tel.: + 00734223363 59, e-mail: Alexey.yuzhakov@pnn.lukoil.com). The contact person for correspondence.

Ivan S. Putilov (Author ID in Scopus: 25723777700) - Doctor of Engineering, Deputy Director of the Branch for Scientific Work in the Field of Geology (tel.: +0073422336458 , e-mail: Ivan.putilov@pnn.lukoil.com).

Южаков Алексей Леонидович - младший научный сотрудник (тел.: + 00734223363 59, e-mail: Alexey.yuzhakov@pnn.lukoil.com). Контактное лицо для переписки. Путилов Иван Сергеевич - доктор технических наук, заместитель директора филиала по научной работе в области геологии (тел.: +007 3422336458 , e-mail: Ivan.putilov@pnn.lukoil.com). 


\section{Introduction}

In Perm Krai, the best studied area is located in its southern part. A big array of information has been collected to further analyse the potential of structures by means of the machine learning method [1]. Data on oil and gas occurrence prediction in local structures unrevealed earlier can be used to decide on a sequence of involving structures into deep exploratory drilling operations [2]. Based on probabilistic and statistical models obtained in the statistical analysis, it is possible to determine parameters that have the most significant influence on oil and gas occurrence. To collect data on parameters, a regional 3D geological model of the studied territory was built [3].

The purpose of this work is to outline Perm Krai reflecting horizon structures, predict their oil and gas occurrence, and evaluate the influence of various parameters on saturation of the structures with hydrocarbons with due regard to a number of various uncertainties [4-20].

\section{Regional 3D Modeling}

of the Southern Part of Perm Krai

The research territory was limited by a modeling framework selected so that all $2 \mathrm{D}$ and $3 \mathrm{D}$ data available on completed seismic surveys could be used to the fullest extent.

The 2D and 3D completed seismic surveys of Perm Krai reflecting horizon are associated with the roof of the Tournaisian carbonate sediments and served as a basis for the regional model. Very close to Perm Krai reflecting horizon, there is one of the main oil and gas play of the Volga-Ural Petroleum and Gas Province: the terrigenous lower Visean oil and gas play [9]. According to the contour lines of the completed seismic surveys in the $2 \mathrm{D}$ and $3 \mathrm{D}$ formats, a single surface of the reflecting horizon was built. To study changes in the reflecting horizon structure, a trend analysis described in [1, 4] was made. Such method allowed us to single out a regional constituent, where big tectonic elements are clearly seen, i.e. Order I structures, domes, deeps, and depressions. By subtracting the regional constituent from the reflecting horizon of the initial surface, a zonal constituent, showing Order II structures (swells, protrusions) was obtained [6-8]. Moreover, a local constituent, in which structures of Order III were determined, was singled out [21]. Fig. 1 shows surfaces of Perm Krai reflecting horizon, its regional, zonal, and local constituents.

Anticlinal and synclinal closures were singled out on the surface of the local constituent. Further, we are going to discuss the anticlinal structures only. For this purpose, on the surface of the local constituent, we outlined the last closed contour lines of the anticline-type structures, which polygons were compared to the polygons of already discovered fields and structures of the known saturation with hydrocarbons. Thus, all the obtained local remainders were divided into three categories: those saturated with hydrocarbons, empty (no hydrocarbons are found there), and predicted ones.

For each structure in a 3D cube the following parameters were calculated: amplitude $(A m p)$, area $(S)$, the highest absolute mark of the structure (Abs.Otm.), the structure intensity (Int), the distance to fracture $(F D)[4,22,23]$. In addition to this, for a quantitative description of the morphology of the local constituent's structures, the cubes containing information on the surface curvature (Dip) and the surface slope azimuth (Dip_az) were calculated in a 3D model. These parameters demonstrate the structural potential of a trap, the ability of the trap to get and store hydrocarbon accumulations.

In addition to the described structural parameters, to predict oil and gas occurrence in the area of research [13], parameters of the hydrocarbon-generating potential of the territory were included. Geochemical parameters of the oil source rock suite reflect the hydrocarbongenerating potential of the territory [5, 10-12]. In our case, the main oil source rock formation is represented by the Semiluk sediments of the Upper Devonian Period [24, 25]. To evaluate hydrocarbon generation capabilities, the following geochemical parameters were included in the regional model: organic carbon content in rock C_org (based on regional maps of $C_{-}$org contents in Semiluk sediments); chloroform extracted bitumen content $(B H L)$; vitrinite reflectance $(R O)$; domanik thickness $\left(M_{-} d m\right)$. The organic carbon content in the rock shows the territory's 


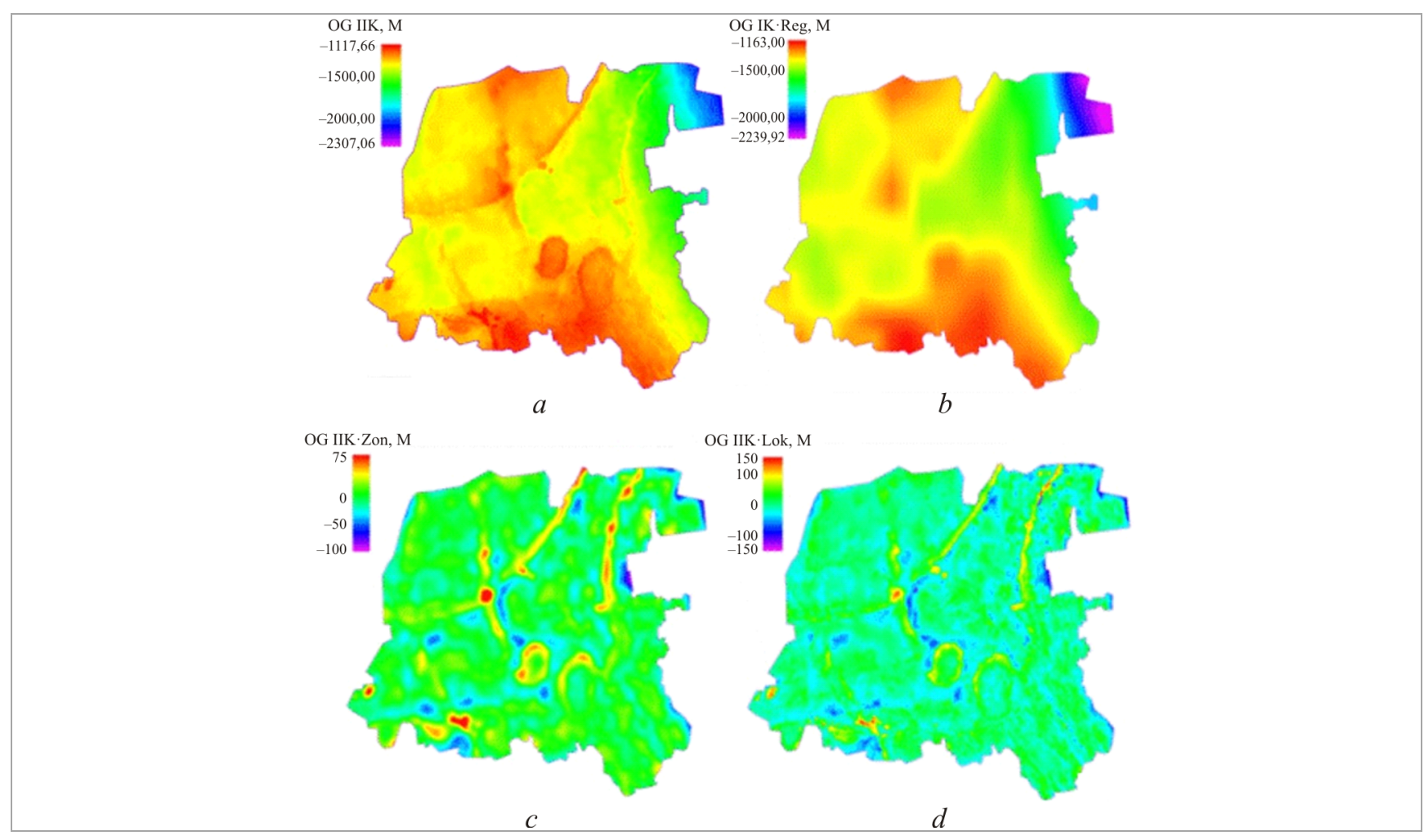

Fig. 1. Surface constituents: $a$ is the constituent of Perm Krai reflecting horizon (m); $b$ is the regional constituent $(\mathrm{m}) ; c$ is the zonal constituent $(\mathrm{m}) ; d$ is the local constituent $(\mathrm{m})$

hydrocarbon-generating potential, as well as the degree of catagenesis-driven transformations in the rock. Vitrinite reflectance shows the transformation degree of the organic matter in the rock, as well as the maturity of the oil source rock by the change in vitrinite contents in it. The content of chloroform extracted bitumen in the area varies from 0 to $6 \%$. The higher the value of this parameter, the more bitumen is contained in the organic matter, which is indicative of oil and gas potential of the oil source rock. The highest values of the content of chloroform extracted bitumen in the rock are registered in the territory of the Bashkir dome and Babkinskaya depression. Moreover, this parameter is slightly increased in the territory of the Verkhnekamskaya depression. Domanik thickness shows the oil source rock thickness, which has a direct influence on oil and gas occurrence in overlying beds. All the above mentioned geochemical parameters, as maps, were downloaded into the regional 3D geological model. Values of these parameters were downloaded for each structure.

Hydrogeological criteria determined in the territory of the research [26] were added as indirect indicators of oil and gas occurrence. The following parameters were selected from hydrogeological parameters: average chlorine and bromine contents in water of the carbonate Visean $C l-B r(V k)$; average sulfur contents in the water of the carbonate Visean - $S(V k)$; water mineralization in the carbonate part of the Visean sediments - $\operatorname{Min}(V k)$; water mineralization in the terrigenous part of the Visean - Min $(V t)$; average sodium and chlorine contents in the water of the terrigenous and carbonate Visean - Na-Cl(Vt), $\mathrm{Na}-\mathrm{Cl}(\mathrm{Vk})$. These parameters were downloaded into the regional model and an averaged value parameter was obtained for each structure.

Hydrogeological parameters are indirect and included in the list of applied criteria to amend the prediction of oil and gas occurrence in the region. The average chlorine and bromine contents in the Visean's water is indicative of oil and gas formation [26]; it is caused by a significant addition of organic genesis bromine in the Visean's water as a result of oil and gas formation. The average chlorine and bromine contents in water of the carbonate Visean in the research territory varies in the range of 166,04 to 
454,6 mg/l. The high sulfur contents in the Visean's water is indicative of the integrity of the oil and gas accumulations, as well as the hydrocarbons themselves. The sulfur content in water of the carbonate Visean is limited to the rage of 0,05 to $2,28 \mathrm{mg} / \mathrm{l}$. High mineralization of the water shows the integrity of hydrocarbon accumulations, the absence of physical and chemical destruction, when there are no salt beds and/or bunches. This figure indirectly indicates favorable conditions for the integrity of the accumulations and absence of mechanical destruction. In addition to this, the water mineralization and data on sodium and chlorine contents in water indirectly indicate favorable hydraulic conditions for the retention of accumulations. The water mineralization in the carbonate part of the Visean varies from 139,66 to $271,31 \mathrm{mg} / \mathrm{l}$, and, in the terrigenous part, it varies from 241,61 to $271,48 \mathrm{mg} / \mathrm{l}$. The average sodium and chlorine contents in water of the terrigenous Visean sediments is within the range of 0,617 to $0,794 \mathrm{mg} / \mathrm{l}$, and in the carbonate Visean, it is within the range of 0,585 to $0,878 \mathrm{mg} / \mathrm{l}$.

Therefore, all types of parameters (structural, geochemical, hydrogeological) provided values for each singled out local remainder. A unified database was developed based on such parameters.

\section{Prediction of Oil and Gas Occurrence in the Southern Part of Perm Krai}

Depending on a selected parameter, individual models, showing the probability of the structure saturation with hydrocarbons, were obtained. The analysis demonstrated that the amplitude had the most important influence on the structure saturation with hydrocarbons. As an example, Fig. 2 shows changes in the probability value of structures' saturation with hydrocarbons depending on the values of parameters used. It is important to note that Ampl parameter demonstrates an insignificant nonlinearity of changes in $P(A m p l)$ value depending on $A m p l$ values; at the same time, $P(A m p l)$ values vary from 0,21 to 0,96 . The dependence of the structural saturation probability change on the surface curvature is nonlinear. The values of the saturation probability vary in the range of 0,32 to
0,98. Among the geochemical parameters, only the dependence of the structural saturation probability change on vitrinite reflectance is inverse; $P(R O)$ values vary from 0,25 to 0,65 . As to all other saturation probability change dependences on geochemical parameters, there is a direct dependence, i.e. the higher the value of a parameter, the higher the probability of the structural saturation with hydrocarbons. Among hydrogeological parameters, the structural saturation probability dependence on the water mineralization of the terrigenous part of the Visean is inverse as well. All other dependences on the hydrogeological parameters are linear and represent a direct relation between the saturation probability and the parameter used. When we checked the correctness of the evaluation of the structural saturation based on the models obtained, the maximum correctness value for the empty structures and for the saturated structures was $61 \%$ and $53 \%$ respectively. The statistical models of predicting oil and gas occurrence based on particular parameters are given in Table 1 .

The analysis of individual probabilistic models shows the presence of dependences of the structural saturation with hydrocarbons on each parameter used, but for a more exact forecast of oil and gas occurrence, a comprehensive approach, including a set of such parameters, should be applied.

It was decided to use the step-by-step linear discriminant analysis (step-by-step LDA) to predict oil and gas occurrence on the basis of a big array of data on structures. The step-by-step LDA based on all parameters allowed us to obtain the saturation probability of the predicted structures in the research territory. The examples and prospects of this method to solve various problems are given in scientific papers $[8,11,27-31]$. The step-by-step LDA allowed us to find a linear combination of characteristics dividing the selection in two [32-45] parts and more. In our case, the selection is made into the empty and saturated structures based on the structural saturation with hydrocarbons. We can apply this method by using relationships between all parameters included in the model in order to find the probability of the predicted structural saturation with hydrocarbons. Before we started, the examination selection that included structures 


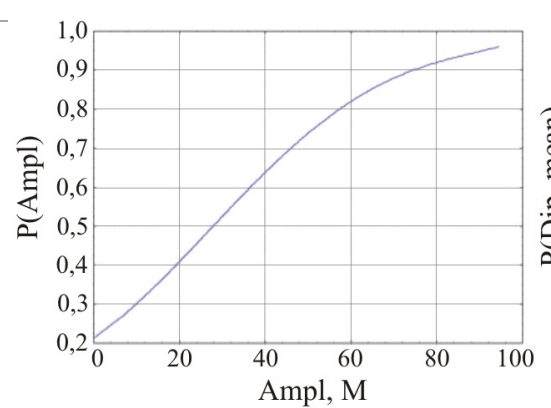

$a$



c

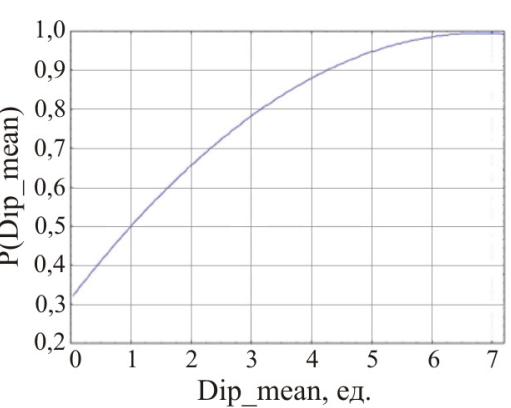

$b$

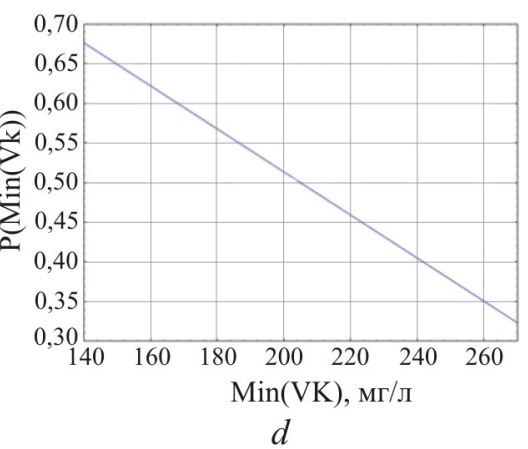

Fig. 2. Change in the probability of the structural saturation with hydrocarbons depending on the following parameters: $a$ - amplitude (m); $b$ - surface curvature (units);

$c$ - vitrinite reflectance $(\%) ; d$-mineralization of water of the carbonate Visean $(\mathrm{mg} / 1)$

of the proved oil and gas occurrence was to contain an equal number of values given for the empty structures and structures saturated with hydrocarbons. Initially, the number of the empty structures was lower than that of the saturated structures; therefore, by means of the random number method, the random empty structures were excluded from the analysis. The examination selection contained 483 structures of known oil and gas occurrence among which 250 structures were saturated with hydrocarbons and 233 structures were empty. The predicted structures in the amount of 228 units were included into the selection, in which the saturation was to be determined by the step-by-step LDA results. During the analysis, the reached level of significance ( $p$-value) was set to 0,05 .

Based on the analysis results the following parameters, included in the statistical model as the parameters having the most significant influence on structures' oil and gas occurrence, were determined: amplitude, mineralization of water in the carbonate part of the Visean sediments, chloroform extracted bitumen content, domanik thickness of the Semiluk sediments, the absolute mark of the structure's dome, vitrinite reflectance, and chlorine and bromine contents in water of the carbonate part of the Visean sediments. In all the above mentioned parameters, the significance level, $p$-value, does not reach the critical point equal to 0,05 unit fractions. In addition to this, the model includes the following: the water mineralization of the terrigenous part of the Visean sediments, the structure intensity, the surface slope azimuth, sodium and chlorine contents in water of the carbonate part of the Visean sediments, and a distance to fractures. $P$-value of significance for such parameters exceeds 0,05 unit fractions. The statistical model did not include the structure's area, its curvature, organic carbon contents in the rock, sulfur contents in the water of the carbonate part of the Visean and sodium and chlorine contents in the terrigenous part of the Visean sediments (Table 2).

The calculation of the evaluation correctness degree showed that for the saturated structures it equals to $78,4 \%$, for the empty structures it equals to $74,7 \%$, and, in general, it equals to $76,6 \%$. The correctness of evaluations obtained with the comprehensive method, in percentage, was higher than that obtained with the use of the individual probabilistic models. The Pearson correlation coefficient also shows a significant difference between the selections of the structures saturated with hydrocarbons and the empty structures. 
Table 1

Statistical models to predict oil and gas occurrence depending on parameters

\begin{tabular}{|c|c|c|c|}
\hline \multirow[b]{2}{*}{ Parameter } & \multirow{2}{*}{$\begin{array}{l}\text { Probability of belonging to the saturated structure class: } \\
\text { upper line; application: central line; probability change } \\
\text { range: lower line }\end{array}$} & \multicolumn{2}{|c|}{ Statistical characteristics of parameters } \\
\hline & & saturated structures & empty structures \\
\hline & $P(A m p l)=0,1832+0,0131 \cdot$ Ampl-0,000048 $\cdot \mathrm{Ampl}^{2}$ & & \\
\hline$A m p L$ amplitude, $\mathrm{m}$ & $\begin{array}{c}1-94 \mathrm{~m} \\
0,21-0,96\end{array}$ & $0,605 \pm 0,231$ & $0,389 \pm 0,172$ \\
\hline & $P(S)=0,4926+9,92 \cdot 10^{-7} \cdot S$ & & \\
\hline$S$ - area, thous. $\mathrm{m}^{2}$ & $\begin{array}{c}40-6900 \text { thous. } \mathrm{m}^{2} \\
0,39-0,91\end{array}$ & $0,562 \pm 0,032$ & $0,426 \pm 0,029$ \\
\hline Dip - surface curvature, units & $\begin{array}{c}P(\text { Dip })=0,3135+0,2005 \cdot \text { Dip-0,0148 } \cdot \text { Dip }^{2} \\
0,04-7,57 \text { units } \\
0,33-0,98\end{array}$ & $0,531 \pm 0,126$ & $0,454 \pm 0,089$ \\
\hline $\begin{array}{l}\text { C_org-organic carbon content in } \\
\text { rock, \% }\end{array}$ & $\begin{array}{c}P\left(C_{-} \text {org }\right)=0,1912+0,0615 \cdot C_{-} \text {org } \\
1,8-5,2 \% \\
0,31-0,71\end{array}$ & $0,535 \pm 0,089$ & $0,499 \pm 0,098$ \\
\hline $\begin{array}{l}B H L-\text { chloroform extracted } \\
\text { bitumen content, } \%\end{array}$ & $\begin{aligned} P(B H L)= & 0,4174+0,079 \cdot \mathrm{BHL} \\
& 0,0-5,0 \% \\
& 0,42-0,79\end{aligned}$ & $0,542 \pm 0,117$ & $0,489 \pm 0,108$ \\
\hline$R O$ - vitrinite reflectance, \% & $\begin{array}{c}P(R O)=0,7897-0,4522 \cdot \mathrm{RO} \\
0,39-1,09 \% \\
0,30-0,61 \\
\end{array}$ & $0,522 \pm 0,039$ & $0,513 \pm 0,053$ \\
\hline$M \_d m$ - domanik thickness, $\mathrm{m}$ & $\begin{array}{c}P\left(M_{-} d m\right)=0,1944+0,0146 \cdot \mathrm{M}_{-} \mathrm{dm} \\
6,75-37,34 \mathrm{~m} \\
0,30-0,73\end{array}$ & $0,532 \pm 0,085$ & $0,503 \pm 0,081$ \\
\hline $\begin{array}{l}\text { Cl-Br(Vk)- chlorine and bromine } \\
\text { content in water of the carbonate } \\
\text { Visean, } \mathrm{mg} / \mathrm{l}\end{array}$ & $\begin{array}{c}P(C l-B r(V k))=0,3299+0,0006 \cdot C l-B r(V k) \\
175,91-409,91 \mathrm{mg} / 1 \\
0,44-0,59\end{array}$ & $0,520 \pm 0,037$ & $0,515 \pm 0,037$ \\
\hline $\begin{array}{l}S(V k) \text { - sulfur content in water of } \\
\text { the carbonate Visean, } \mathrm{mg} / \mathrm{l}\end{array}$ & $\begin{array}{c}P(S(V k))=0,3582+0,1803 \cdot \mathrm{S}(\mathrm{Vk}) \\
0,07-2,26 \mathrm{mg} / 1 \\
0,37-0,75\end{array}$ & $0,536 \pm 0,104$ & $0,497 \pm 0,089$ \\
\hline $\begin{array}{l}\operatorname{Min}(V k) \text { - mineralization of water } \\
\text { of the carbonate Visean, } \mathrm{mg} / \mathrm{l}\end{array}$ & $\begin{array}{c}P(\operatorname{Min}(\text { Vk }))=1,0573-0,0027 \cdot \operatorname{Min}(\mathrm{Vk}) \\
142,25-267,09 \mathrm{mg} / 1 \\
0,33-0,66\end{array}$ & $0,538 \pm 0,103$ & $0,496 \pm 0,099$ \\
\hline $\begin{array}{l}\mathrm{Na}-\mathrm{Cl}(\mathrm{Vk}) \text { - sodium and chlorine } \\
\text { content in water of the carbonate } \\
\text { Visean, } \mathrm{mg} / \mathrm{l}\end{array}$ & $\begin{array}{c}P(\mathrm{Na}-\mathrm{Cl}(\mathrm{Vk}))=-0,4405+1,2611 \cdot \mathrm{Na}-\mathrm{Cl}(\mathrm{Vk}) \\
0,59-0,88 \mathrm{mg} / 1 \\
0,32-0,66\end{array}$ & $0,526 \pm 0,067$ & $0,509 \pm 0,063$ \\
\hline $\begin{array}{l}\operatorname{Min}(V t)-\text { mineralization of water } \\
\text { of the terrigenous Visean, } \mathrm{mg} / \mathrm{l}\end{array}$ & $\begin{array}{c}P(\operatorname{Min}(V t))=-1,4819+0,0076 \cdot \operatorname{Min}(\mathrm{Vt}) \\
243,48-271,48 \mathrm{mg} / 1 \\
0,38-0,59\end{array}$ & $0,521 \pm 0,037$ & $0,514 \pm 0,038$ \\
\hline
\end{tabular}

It equals to 209,97 units, which is much higher than the critical value $(3,841$ units) and exceeds values obtained with the use of one group of parameters to determine the potential saturation of structures. The ratio of the calculated Fisher criterion to the theoretical Fisher criterion is $F p / F t=23,8$.

As a result of the step-by-step LDA, the following linear discriminant function was obtained:

$$
\begin{gathered}
Z=-1,084-0,033 \cdot \text { Ampl }+0,006 \cdot \text { Abs. Otm. }- \\
-0,067 \cdot F D+0,007 \cdot \operatorname{Dip} a z+0,009 \cdot M i n(V k)- \\
-0,033 \cdot M i n(V k)-0,22 \cdot B H L-0,057 \cdot I n t- \\
-0,058 \cdot M_{d m}-7,716 \cdot R O+0,005 \mathrm{ClBr}(V k)+ \\
+4,376 \cdot \mathrm{NaCl}(V k)
\end{gathered}
$$

$$
\text { clas }=76,6 \% ; F p / F t=23,8 ; p<0,00001,
$$

where clas is the percentage of the correct classification; $F p / F t$ is the ratio of the calculated Fisher criterion to the theoretical Fisher criterion; $p$ is the significance level.

Based on this function, we determined the probability values of belonging to the class of the saturated (oil-bearing) structures $P(Z)$. It was established that, when $Z$ values alter from negative to positive ones, $P(Z)$ values naturally decrease. The dependence of $P(Z)$ on $Z$ is given in Fig. 3. The average $Z$ value for the saturated structures and empty structures is equal to 0,72 and to 0,76, respectively. At the same time, the 
Table 2

Results of the step-by-step LDA for a set of parameters

\begin{tabular}{|c|c|c|c|c|}
\hline Parameters $(n=483)$ & Conventional sign & $P$-value & Wilks' lambda & $\begin{array}{l}\text { Coefficients for } \\
\text { canonical variables }\end{array}$ \\
\hline \multicolumn{5}{|c|}{ Parameters included in the statistical model } \\
\hline Amplitude & Ampl & 0,000 & 0,789 & $-0,033$ \\
\hline Mineralization of water of the carbonate part of the Visean & $\operatorname{Min}(\mathrm{Vk})$ & 0,020 & 0,650 & 0,009 \\
\hline Mineralization of water of the terrigenous part of the Visean & $\operatorname{Min}(\mathrm{Vt})$ & 0,081 & 0,646 & $-0,033$ \\
\hline Chloroform extracted bitumen content & BHL & 0,001 & 0,656 & $-0,220$ \\
\hline Intensity & Int & 0,613 & 0,643 & $-0,057$ \\
\hline Domanik thickness & M_dm & 0,001 & 0,656 & $-0,058$ \\
\hline Absolute mark & Abs.Otm. & 0,000 & 0,667 & 0,006 \\
\hline Vitrinite reflectance & RO & 0,000 & 0,663 & $-7,716$ \\
\hline $\begin{array}{l}\text { Chlorine and bromine content in the carbonate part of the } \\
\text { Visean }\end{array}$ & Cl-Br(Vk) & 0,018 & 0,646 & 0,005 \\
\hline Surface slope azimuth & Dip_az & 0,099 & 0,645 & 0,007 \\
\hline $\begin{array}{l}\text { Sodium and chlorine content in the carbonate part of the } \\
\text { Visean }\end{array}$ & $\mathrm{Na}-\mathrm{Cl}(\mathrm{Vk})$ & 0,130 & 0,645 & 4,376 \\
\hline Distance to fractures & FD & 0,276 & 0,644 & $-0,067$ \\
\hline \multicolumn{5}{|c|}{ Parameters not included in the statistical model } \\
\hline Area & $\mathrm{S}$ & 0,798 & 0,642 & Constant term \\
\hline Surface curvature & Dip & 0,653 & 0,642 & $-1,084$ \\
\hline Organic carbon content in rock & C_org & 0,339 & 0,641 & - \\
\hline Sulfur content in the carbonate part of the Visean & S(Vk) & 0,561 & 0,642 & - \\
\hline $\begin{array}{l}\text { Sodium and chlorine content in the terrigenous part of the } \\
\text { Visean }\end{array}$ & $\mathrm{Na}-\mathrm{Cl}(\mathrm{Vt})$ & 0,508 & 0,642 & - \\
\hline
\end{tabular}

average $P(Z)$ value for the structures saturated with hydrocarbons and for the empty structures is equal to 0,69 and 0,32 , respectively.

In total, 174 potentially empty structures and 54 structures saturated with hydrocarbons were obtained [38]. The location scheme of the oil fields and potential structures in the southern part Perm Krai shows that the structures potentially saturated with hydrocarbons are located next to already discovered fields. Such structures are singled out at a small distance from the Shumovskoye field, Nozhovskaya group of fields, Kokuiskoye field, Shagirtsko-Gozhanskoye field and others. It should be noted that a big amount of the potential structures are concentrated in the south-eastern part of Perm Krai and located next to the Veslyanskaya swell-like zone and Dorokhovsky swell. Big structures were singled out in the regions of the Verkhnekamskaya depression, Perm dome, and Babkinskaya depression. Smaller structures refer to the Bashkir dome and Bymsko-Kungur monocline.

\section{Explanation of New Boundaries of Oil and Gas Geological Zoning of the Territory}

Individual probabilistic models built for each parameter allowed us to receive a dependence of the saturation on the parameter values; such dependence is described by a linear function. These functions were used in the 3D regional model to develop cubes based on the previously calculated parameters. In this way, the probabilities of saturation depending on each parameter were obtained and classified by the type of parameters (structural, geochemical, and hydrogeological). The summarized maps of the territory's saturation probability were obtained by summing up the probability maps of the used parameters and divided by their number. After that, the regional maps of saturation were obtained based on the structural, geochemical, and hydrogeological parameters, which served as a basis for a comprehensive map of the structures' saturation in the southern part of Perm Krai (Fig. 4).

The map shows the probability of the territory's saturation with hydrocarbons and, based on this map, it is possible to amend boundaries of the current oil and gas geological zoning in the research region. New suggested boundaries of the oil and gas geological zoning are associated with the boundaries of the territory's saturation probability, which were obtained as a result of the analysis described above. The map showing the alteration of the area zoning boundaries is also shown in Fig. 4. 


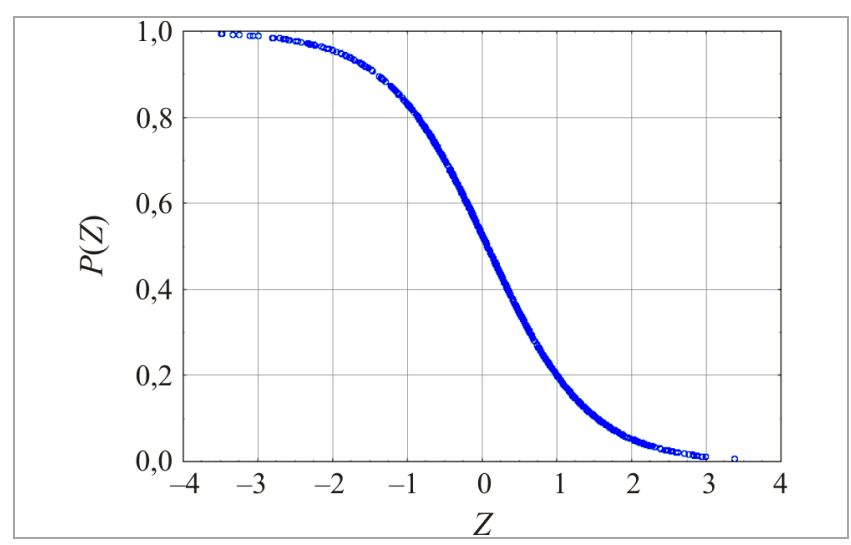

Fig. 3. Dependence of $P(Z)$ on $Z$

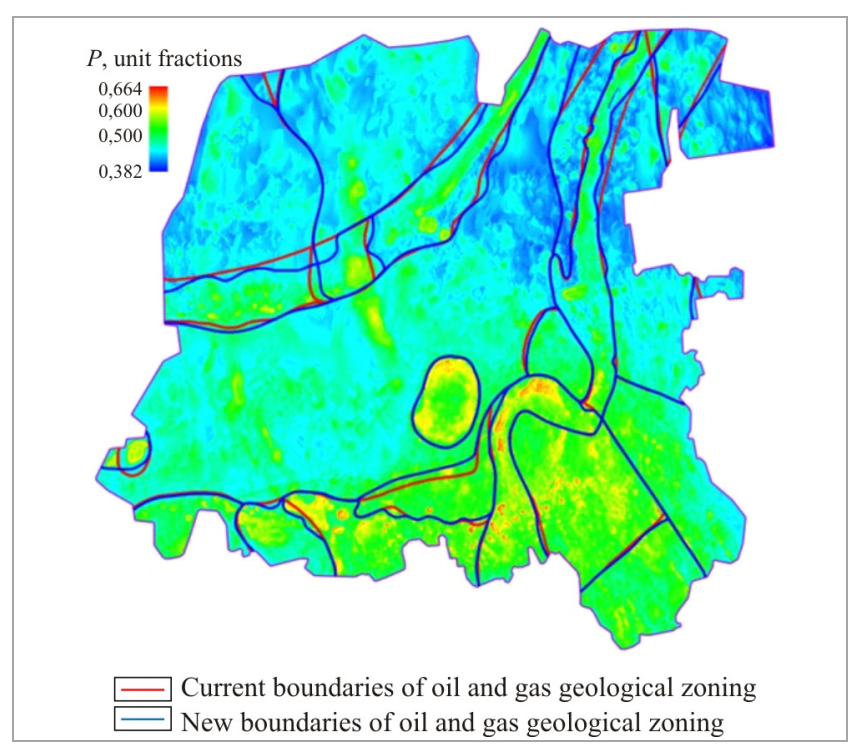

Fig.4. Regional map of the probability of the researched territory saturation with hydrocarbons showing boundaries of oil and gas geological zoning (red colour corresponds to the current boundaries and blue colour corresponds to the new boundaries)

\section{Conclusion}

During the research, we built the 3D regional geological model, which allows a comprehensive analysis and obtaining data on structural, geochemical, and hydrogeological parameters.

The 3D regional geological model resulted in revealing the local remainders, which saturation with hydrocarbons is still unknown.

The analysis of the individual probabilistic curves gives us a possibility to evaluate the influence of the separate parameters on the saturation of structures with hydrocarbons and single out more informative ones among them.
In order to predict oil and gas occurrence of the potential structures, a step-by-step linear discriminant analysis was applied. Based on the analysis results, the statistical model of the structural saturation probability was built for the southern part of Perm Krai. Moreover, information about the potential saturation of the local remainders, unstudied previously, is received.

Based on the individual probabilistic models and with the employment of all the used parameters, the regional map of saturation of the researched territory with hydrocarbons was built. The regional map of the saturation probability with hydrocarbons allowed us to amend boundaries of theoil and gas geological zoning.

\section{References}

1. Iuzhakov A.L. Klassifikatsiia strukturnykh lokal'nykh ostatkov otrazhaiushchego gorizonta IIK na primere iuga Permskogo kraia [Classification of structural local remains of the reflective horizon IIK on the example of the south of the Perm Krai]. Problemy razrabotki mestorozhdenii uglevodorodnykh $i$ rudnykh poleznykh iskopaemykh. Materialy XI Vserossiiskoi nauchno-tekhnicheskoi konferentsii, 7-9 November 2018, Perm, 2018, 85 p.

2. Putilov I.S., Ladeishchikov S.V. Kompleksnyi podkhod pri seismofatsial'nom raionirovanii nizhnebobrikovskikh otlozhenii Chashkinskogo mestorozhdeniia [An integrated approach for seismic facies zoning of the Lower Bobrikov deposits of the Chashkinskoye field]. Teoriia i praktika razvedochnoi i promyslovoi geofiziki. Materialy mezhdunarodnoi nauchnoprakticheskoi konferentsii, 26-27 November 2015. Perm, Permskii natsional'nyi issledovatel'skii politekhnicheskii universitet, 2015, pp. 150-154.

3. Putilov I.S. Trekhmernoe geologicheskoe modelirovanie pri razrabotke neftianykh i gazovykh mestorozhdenii [3D geological modeling in the development of oil and gas fields]. Perm, Permskii natsional'nyi issledovatel'skii politekhnicheskii universitet, 2011, 72 p. 
4. Putilov I.S., Galkin V.I. Razrabotka metodiki veroiatnostno-statisticheskogo prognoza neftegazonosnosti lokalizovannykh struktur (na primere iuzhnoi chasti Permskogo kraia) [Developing the technology for probabilistic and statistical forecast of oil-andgas-bearing capacity of the south Perm region]. Neftianoe khoziaistvo, 2014, no. 4, pp. 26-29.

5. Putilov I.S., Solov'ev S.I., Obukhov A.A., Piatunina E.V. Kompleksnyi podkhod $\mathrm{k}$ izucheniiu domanikovykh otlozhenii na territorii Permskogo kraia [An integrated approach to the study of Domanik deposits in the Perm region]. Perspektivy uvelicheniia resursnoi bazy razrabatyvaemykh otlozhenii, $v$ tom chisle iz domanikovykh otlozhenii. Sbornik dokladov po itogam mezhregional'noi nauchnoprakticheskoi konferentsii, posviashchennoi 70-letiiu NGDU "Leninogorskneft", 6-7 August 2015, Karabash, PAO "Tatneft". Al'met'evsk, 2015, pp. 71-78.

6. Krivoshchekov S.N. Razrabotka regional'no-zonal'nykh kriteriev prognoza neftegazonosnosti territorii Permskogo Prikam'ia veroiatnostno-statisticheskimi metodami [Establishment of regional and zonal criteria of Perm region`s oil forecast probabilistic and statistical methods]. Neftianoe khoziaistvo, 2011, no. 10, pp. 10-14.

7. Krivoshchekov S.N., Galkin V.I., Volkova A.S. Razrabotka veroiatnostno-statisticheskoi metodiki prognoza neftegazonosnosti struktur [Development of a probabilistic-statistical method for predicting the oil and gas content of structures]. Neftepromyslovoe delo, 2010, no. 7, pp. 28-31.

8. Melkishev O.A., Galkin V.I., Kozhevnikova E.E., Karaseva T.V. Zonal'nyi prognoz neftegazonosnosti devonskogo terrigennogo neftegazonosnogo kompleksa na iuge Permskogo kraia [Prediction of zonal hydrocarbon potentials Devonian clastic sediments on the south of Perm region]. Neftianoe khoziaistvo, 2014, no. 6, pp. 4-8.

9. Kovalevskiy E. Geological Modelling on the Base of Geostatistics: Course Note. Student Lecture Tour. RUSSIA \& CIS, 2011-2012.
10. Krivoshchèkov S.N., Kochnev A.A., Sannikov I.V. Perspektivy neftegazonosnosti otlozhenii domanikovogo tipa na territorii Permskogo kraia [Oil and gas prospects of domanic sediments in Perm krai]. Vestnik Permskogo natsional'nogo issledovatel'skogo politekhnicheskogo universiteta. Geologiia. Neftegazovoe $i$ gornoe delo, 2013, no. 9, pp. 18-26. DOI: $10.15593 / 2224-9923 / 2013.9 .2$

11. Galkin V.I., Kozlova I.A., Melkishev O.A., Shadrina M.A. Geokhimicheskie pokazateli ROV porod kak kriterii otsenki perspektiv neftegazonosnosti [Geochemical indicators of dispersed organic matter (DOM) of rocks as criteria of hydrocarbon potential evaluation]. Neftepromyslovoe delo, 2013, no. 9, pp. 28-31.

12. Diubrul' O. Ispol'zovanie geostatistiki dlia vkliucheniia $\mathrm{v}$ geologicheskuiu model' seismicheskikh dannykh [Using geostatistics to include seismic data in a geological model]. Moscow: Evropeiskaia assotsiatsiia geouchenykh i inzhenerov (EAGE), 2002, $296 \mathrm{p}$.

13. Voevodkin V.L., Galkin V.I., Krivoshchekov S.N. Issledovanie vliianiia kriteriev neftegazonosnosti i izuchennosti territorii Permskogo kraia na raspredelenie mestorozhdenii uglevodorodov [Investigation of the effect of oil-content and research criteria in the Perm region on the hydrocarbon deposits distribution]. Neftianoe khoziaistvo, 2012, no. 6 , pp. 30-34.

14. Galkin V.I., Karaseva T.V., Kozlova I.A., Nosov M.A., Krivoshchekov S.N. Differentsirovannaia veroiatnostnaia otsenka generatsionnykh protsessov $\mathrm{v}$ otlozheniiakh domanikovogo tipa Permskogo kraia [Differentiated probabilistic assessment of the generation processes in Domanic sediments of Perm region]. Neftianoe khoziaistvo, 2014, no. 12, pp. 103-105.

15. Altunin A.E., Semukhin M.V. Raschety v usloviiakh riska i neopredelennosti $\mathrm{v}$ neftegazovykh tekhnologiiakh [Calculations under the conditions of risk and uncertainty in oil and gas technologies]. Moscow; Tyumen: Tiumenskii gosudarstvennyi universitet, 2004, 296 p. 
16. Ampilov Iu.P. Metody geologoekonomicheskogo modelirovaniia resursov $i$ zapasov nefti i gaza $s$ uchetom neopredelennosti i riska [Methods for geological and economic modeling of oil and gas resources and reserves, taking into account uncertainty and risk]. Moscow: Geoinformmark, 2002, $201 \mathrm{p}$.

17. Galkin S.V. Veroiatnostnyi prognoz geologicheskikh riskov pri poiskakh mestorozhdenii nefti i gaza [Probabilistic forecast of geological risks in prospecting for oil and gas fields]. Perm: Knizhnyi mir, 2009, 224 p.

18. Kurchikov A.R., Borodkin V.N., Galkin S.V., Galkin V.I., Rastegaev A.V. Metodika veroiatnostnoi otsenki geologicheskikh riskov pri poiskakh neftianykh mestorozhdenii dlia territorii $s$ vysokoi plotnost'iu promyshlennykh otkrytii [Some method of probability assessment of geological risks while prospecting for oil fields on territories with high density of commercial discoveries]. Geologiia, geofizika $i$ razrabotka neftianykh $i$ gazovykh mestorozhdenii, 2013, no. 10, pp. 4-13.

19. Fokin. A. Riski i neopredelennosti $\mathrm{v}$ geologorazvedochnom protsesse [Risks and uncertainties in the exploration process]. Novator, 2011, no. 43, pp. 8-12.

20. Meisner J., Demirmen F. The creaming method: a bayesian procedure to forecast future oil and gas discoveries in mature exploration provinces. Journal of the Royal Statistical Society. Series A, 1981, vol. 144, no. $1, \quad$ pp. 1-31. DOI: $10.2307 / 2982158$

21. Cosentino L. Integrated reservoir studies. Paris: Editions Technip, 2001, $400 \mathrm{p}$.

22. Galkin V.I., Kozlova I.A., Rastegaev A.V., Vantseva I.V., Krivoshchekov S.N., Voevodkin V.L. $\mathrm{K}$ metodike otsenki perspektiv neftegazonosnosti Solikamskoi depressii po kharakteristikam lokal'nykh struktur [Estimation procedure of petroleum potential of Solikamsk depression based on local structures parameters]. Neftepromyslovoe delo, 2010, no. 7.
23. Putilov I.S. Nauchnoe obosnovanie veroiatnostno-statisticheskikh metodov prognoza neftegazonosnosti struktur $\mathrm{v}$ usloviiakh vysokoizuchennykh territorii [Scientific substantiation of probabilistic and statistical methods for predicting the oil and gas content of structures in the conditions of highly explored territories]. Perm, 2016, $369 \mathrm{p}$.

24. Stupakova A.V., Fadeeva N.P., Kalmykov G.A., Bogomolov A.Kh., Kiriukhina T.A., Korobova N.I., Shardanova T.A., Suslova A.A., Sautkin R.S., Poludetkina E.N., Kozlova E.V., Mitronov D.V., Korkots F.V. Poiskovye kriterii nefti i gaza $\mathrm{v}$ domanikovykh otlozheniiakh Volgo-Ural'skogo basseina [Criteria for oil and gas search in domanic deposits of the Volga-Ural basin]. Georesursy, 2015, no. 2 (61), pp. 77-86. DOI: $10.18599 /$ grs.61.2.7

25. Nosov M.A., Galkin V.I., Krivoshchekov S.N., Melkishev O.A. Otlozheniia domanikovogo tipa - vozmozhnyi istochnik netraditsionnykh uglevodorodov dlia Permskogo kraia: obzor, perspektivy, rekomendatsii [Domanik type rocks - a possible source of nonconventional hydrocarbons for the Perm region: an overview, perspectives, recommendations]. Neftianoe khoziaistvo, 2012, no. 10 , pp. $90-91$.

26. Kartsev A.A. Gidrogeologiia neftianykh i gazovykh mestorozhdenii [Hydrogeology of oil and gas fields]. Moscow: Nedra, 1972, $280 \mathrm{p}$.

27. Galkin V.I., Kozlova I.A., Rastegaev A.V., Vantseva I.V., Krivoshchekov S.N., Voevodkin V.L. $\mathrm{K}$ metodike otsenki perspektiv neftegazonosnosti Solikamskoi depressii po kharakteristikam lokal'nykh struktur [Estimation procedure of petroleum potential of Solikamsk depression based on local structures parameters]. Neftepromyslovoe delo, 2010, no. 7, pp. 12-17.

28. Galkin V.I., Rastegaev A.V., Galkin S.V. Veroiatnostno-statisticheskaia otsenka neftegazonosnosti lokal'nykh struktur [Probabilisticstatistical assessment of oil and gas content of local structures]. Yekaterinburg, 2011, $299 \mathrm{p}$. 
29. Galkin V.I., Sosnin N.E. Razrabotka geologo-matematicheskikh modelei dlia prognoza neftegazonosnosti slozhnopostroennykh struktur $\mathrm{V}$ devonskikh terrigennykh otlozheniiakh [Geological development of mathematical models for the prediction of oil and gas complex-built structures in the Devonian clastic sediments]. Neftianoe khoziaistvo, 2013, no. 4, pp. 28-31.

30. Meng L., Zhen L., Minzhu L., Huilai Z. Prediction of residual oil saturation by using the ratio of amplitude of time-lapse seismic data. Geophysics, 2017, vol. 82, no. 1, pp. 1-12. DOI: $10.1190 /$ geo2015-0453.1

31. Yarus J.M. Stochastic modeling and geostatistics. AAPG. Tulsa, Oklahoma, 1994, $231 \mathrm{p}$.

32. Davis J.C. Statistics and Data Analysis in Geology. 3Rd Edition. John Wiley \& Sons, 2002. $656 \mathrm{p}$.

33. C.V. Deutsch Geostatistical Reservoir modelling. Oxford University Press, 2002.

34. Armstrong M. Basic Linear Geostatistics. Springer, 1998, $155 \mathrm{p}$.

35. Devis Dzh.S. Statisticheskii analiz dannykh $\mathrm{v}$ geologii [Statistical data analysis in geology]. Moscow: Nedra, 1990, book 1, $319 \mathrm{p}$.

36. Devis Dzh.S. Statisticheskii analiz dannykh $\mathrm{v}$ geologii [Statistical data analysis in geology]. Moscow: Nedra, 1990, book 2, $426 \mathrm{p}$.

37. Rodionov D.A., Kogan R.I., Golubeva V.A. et al. Spravochnik po matematicheskim metodam $\mathrm{v}$ geologii [A Handbook of Mathematical Methods in Geology]. Moscow: Nedra, 1987, $335 \mathrm{p}$.

38. Iuzhakov A.L. Prognoz neftegazonosnosti struktur po tektonicheskim elementam otrazhaiushchego gorizonta IIK iuzhnoi chasti Permskogo kraia [Forecast oil and gas bearing structures of tectonic elements of the reflector IIK the southern part of the Perm region]. Novye napravleniia neftegazovoi geologii $i$ geokhimii. Razvitie geologorazvedochnykh materialov II Mezhdunarodnoi nauchnoi konferentsii. Perm, 2019, pp. 195-200.

39. Johnson N.L., Leone F.C. Statistics and experimental design. New York - London - Sydney Toronto, 1977, $606 \mathrm{p}$.

40. Montgomery D.C., Peck E.A. Introduction to linear regression analysis. New York: John Wiley \& Sons, 1982, 504 p.

41. Yarus J.M. Stochastic modeling and geostatistics. AAPG. Tulsa, Oklahoma, 1994, $231 \mathrm{p}$.

42. Houze O., Viturat D., Fjaere O.S. Dinamie data analysis. Paris: Kappa Engineering, 2008, 694 p.

43. GSLIB: Geostatistical Software Library and User's Guide. New York: Oxford University Press, 1998, 369 p.

44. Isaaks E.H., Srivastava R.M. An Introduction to Applied Geostatistics. Oxford University Press, 1989, 561 p.

45. Kaufman M.G. Statistical issues in the assessment of undiscovered oil and gas resources. MITCEEPR, 1992, $30 \mathrm{p}$.

\section{Библиографический список}

1. Южаков А.Л. Классификация структурных локальных остатков отражающего горизонта IIК на примере юга Пермского края // Проблемы разработки месторождений углеводородных и рудных полезных ископаемых: материалы XI Всерос. науч.техн. конф., г. Пермь, 7-9 ноября 2018 г. Пермь, 2018. - С. 85.

2. Путилов И.С., Ладейщиков С.В. Комплексный подход при сейсмофациальном районировании нижнебобриковских отложений Чашкинского месторождения // Теория и практика разведочной и промысловой геофизики: материалы междунар. науч.практ. конф., г. Пермь 26-27 ноября 2015 г. / Перм. гос. нац. исслед. ун-т. - Пермь, 2015. C. $150-154$.

3. Путилов И.С. Трехмерное геологическое моделирование при разработке нефтяных и газовых месторождений. - Пермь: Изд-во Перм. нац. исслед. политехн. ун-та, 2011. $72 \mathrm{c}$.

4. Путилов И.С., Галкин В.И. Разработка методики вероятностно-статистического 
прогноза нефтегазоносности локализованных структур (на примере южной части Пермского края) // Нефтяное хозяйство. - 2014. № 4. - С. 26-29.

5. Комплексный подход к изучению доманиковых отложений на территории Пермского края / И.С. Путилов, С.И. Соловьев, А.А. Обухов, Е.В. Пятунина // Перспективы увеличения ресурсной базы разрабатываемых отложений, в том числе из доманиковых отложений: сборник докладов по итогам межрегион. науч.-практ. конф., посвященной 70-летию НГдУ «Лениногорскнефть», Карабаш, 6-7 августа 2015 г. / ПАО «Татнефть». - Альметьевск, 2015. C. 71-78.

6. Кривощеков С.Н. Разработка регионально-зональных критериев прогноза нефтегазоносности территории Пермского Прикамья вероятностно-статистическими методами // Нефтяное хозяйство. - 2011. № 10. - С. 10-14.

7. Кривощеков С.Н., Галкин В.И., Волкова А.С. Разработка вероятностно-статистической методики прогноза нефтегазоносности структур // Нефтепромысловое дело. - 2010. № 7. - С. 28-31.

8. Зональный прогноз нефтегазоносности девонского терригенного нефтегазоносного комплекса на юге Пермского края / О.А. Мелкишев, В.И. Галкин, Е.Е. Кожевникова, Т.В. Карасева // Нефтяное хозяйство. - 2014. № 6. - C. 4-8.

9. Kovalevskiy E. Geological Modelling on the Base of Geostatistics: Course Note. Student Lecture Tour. - RUSSIA \& CIS, 2011-2012.

10. Кривощеков С.Н., Кочнев А.А., Санников И.В. Перспективы нефтегазоносности отложений доманикового типа на территории Пермского края // Вестник Пермского национального исследовательского политехнического университета. Геология. Нефтегазовое и горное дело. - 2013. - № 9. - С. 18-26. DOI: $10.15593 / 2224-9923 / 2013.9 .2$

11. Геохимические показатели РОВ пород как критерии оценки перспектив нефтегазоносности / В.И. Галкин, И.А. Козлова, О.А. Мелкишев, М.А. Шадрина //
Нефтепромысловое дело. - 2013. - № 9. C. 28-31.

12. Дюбруль О. Использование геостатистики для включения в геологическую модель сейсмических данных / Евр. ассоциация геоученых и инженеров (EAGE). - M., 2002. - 296 c.

13. Воеводкин В.Л., Галкин В.И., Кривощеков С.Н. Исследование влияния критериев нефтегазоносности и изученности территории Пермского края на распределение месторождений углеводородов // Нефтяное хозяйство. - 2012. - № 6. - С. 30-34.

14. Дифференцированная вероятностная оценка генерационных процессов в отложениях доманикового типа Пермского края / В.И. Галкин, Т.В. Карасева, И.А. Козлова, М.А. Носов, С.Н. Кривощеков // Нефтяное хозяйство. - 2014. - № 12. - С. 103-105.

15. Алтунин А.Е., Семухин М.В. Расчеты в условиях риска и неопределенности в нефтегазовых технологиях. - М.; Тюмень: Изд-во Тюмен. гос. ун-та, 2004. - 296 с.

16. Ампилов Ю.П. Методы геологоэкономического моделирования ресурсов и запасов нефти и газа с учетом неопределенности и риска. - М.: Геоинформмарк, 2002. - 201 с.

17. Галкин С.В. Вероятностный прогноз геологических рисков при поисках месторождений нефти и газа. - Пермь: Книжный мир, 2009. - 224 с.

18. Методика вероятностной оценки геологических рисков при поисках нефтяных месторождений для территорий $\mathrm{c}$ высокой плотностью промышленных открытий / А.Р. Курчиков, В.Н. Бородкин, С.В. Галкин, В.И. Галкин, А.В. Растегаев // Геология, геофизика и разработка нефтяных и газовых месторождений. - 2013. - № 10. - С. 4-13.

19. Фокин. А. Риски и неопределенности в геологоразведочном процессе // Новатор. 2011. - № 43. - C. 8-12.

20. Meisner J., Demirmen F. The creaming method: a bayesian procedure to forecast future oil and gas discoveries in mature exploration provinces // Journal of the Royal Statistical Society. Series A. - 1981. - Vol. 144, № 1. P. 1-31. DOI: $10.2307 / 2982158$ 
21. Cosentino L. Integrated reservoir studies. - Paris: Editions Technip, 2001. $400 \mathrm{p}$.

22. К методике оценки перспектив нефтегазоносности Соликамской депрессии по характеристикам локальных структур / В.И. Галкин, И.А. Козлова, А.В. Растегаев, И.В. Ванцева, С.Н. Кривощеков, В.Л. Воеводкин // Нефтепромысловое дело. - 2010. - № 7. C. $12-17$.

23. Путилов И.С. Научное обоснование вероятностно-статистических методов прогноза нефтегазоносности структур в условиях высокоизученных территорий. - Пермь, 2016. - 369 c.

24. Поисковые критерии нефти и газа в доманиковых отложениях Волго-Уральского бассейна / А.В. Ступакова, Н.П. Фадеева, Г.А. Калмыков, А.Х. Богомолов, Т.А. Кирюхина, Н.И. Коробова, Т.А. Шарданова, А.А. Суслова, Р.С. Сауткин, Е.Н. Полудеткина, Е.В. Козлова, Д.В. Митронов, Ф.В. Коркоц // Георесурсы. - 2015. - № 2 (61). - С.77-86. DOI: 10.18599/grs.61.2.7

25. Отложения доманикового типа возможный источник нетрадиционных углеводородов для Пермского края: обзор, перспективы, рекомендации / М.А. Носов, В.И. Галкин, С.Н. Кривощеков, О.А. Мелкишев // Нефтяное хозяйство. - 2012. - № 10. C. 90-91.

26. Карцев А.А. Гидрогеология нефтяных и газовых месторождений. - М.: Недра, 1972. $-280 \mathrm{c}$.

27. К методике оценки перспектив нефтегазоносности Соликамской депрессии по характеристикам локальных структур / В.И. Галкин, И.А. Козлова, А.В. Растегаев, И.В. Ванщева, С.Н. Кривощеков, В.Л. Воеводкин // Нефтепромысловое дело. - 2010. - № 7. C. 12-17.

28. Галкин В.И., Растегаев А.В., Галкин С.В. Вероятностно-статистическая оценка нефтегазоносности локальных структур. Екатеринбург, 2011. - 299 с.

29. Галкин В.И., Соснин Н.Е. Разработка геолого-математических моделей для прогноза нефтегазоносности сложнопостроенных структур в девонских терригенных отложениях // Нефтяное хозяйство. - 2013. № 4. - C. 28-31.

30. Prediction of residual oil satiration by using the ratio of amplitude of time-lapse seismic data / L. Meng, L. Zhen, L. Minzhu, Z. Huilai // Geophysics. - 2017. - Vol. 82, № 1. - P. 1-12. DOI: $10.1190 /$ geo2015-0453.1

31. Yarus J.M. Stochastic modeling and geostatistics // AAPG. - Tulsa, Oklahoma, 1994. $231 \mathrm{p}$.

32. Davis J.C. Statistics and Data Analysis in Geology. - 3Rd Edition. - John Wiley \& Sons, 2002. $-656 \mathrm{p}$.

33. C.V. Deutsch Geostatistical Reservoir modelling. - Oxford University Press, 2002.

34. Armstrong M. Basic Linear Geostatistics. Springer, 1998. - $155 \mathrm{p}$.

35. Девис Дж.С. Статистический анализ данных в геологии. - М.: Недра, 1990. - Кн. 1. 319 c.

36. Девис Дж.С. Статистический анализ данных в геологии. - М.: Недра, 1990. Кн. 2. -426 с.

37. Справочник по математическим методам в геологии / Д.А. Родионов, Р.И. Коган, В.А. Голубева [и др.]. - М.: Недра, 1987. - 335 c.

38. Южаков А.Л. прогноз нефтегазоносности структур по тектоническим элементам отражающего горизонта IIK южной части Пермского края // Новые направления нефтегазовой геологии и геохимии. Развитие геологоразведочных работ: сборник материалов II Междунар. науч. конф. - Пермь, 2019. C. $195-200$.

39. Johnson N.L., Leone F.C. Statistics and experimental design. - New York London - Sydney - Toronto, 1977. $606 \mathrm{p}$.

40. Montgomery D.C., Peck E.A., Introduction to linear regression analysis. New York: John Wiley \& Sons, 1982. $504 \mathrm{p}$.

41. Yarus J.M. Stochastic modeling and geostatistics // AAPG. - Tulsa, Oklahoma, 1994. - $231 \mathrm{p}$. 
42. Houze O., Viturat D., Fjaere O.S. Dinamie data analysis. - Paris: Kappa Engineering, 2008. $694 \mathrm{p}$.

43. GSLIB: Geostatistical Software Library and User's Guide. - New York: Oxford University Press, 1998. - 369 p.
44. Isaaks E.H., Srivastava R.M. An Introduction to Applied Geostatistics. - Oxford University Press, 1989. - 561 p.

45. Kaufman M.G. Statistical issues in the assessment of undiscovered oil and gas resources. MITCEEPR, 1992. - 30 p.

Please cite this article in English as:

Yuzhakov A.L., Putilov I.S. Forecasting the oil and gas content of the southern part of the Perm Krai using regional three-dimensional modeling. Perm Journal of Petroleum and Mining Engineering, 2020, vol.20, no.4, pp.317-330. DOI: $10.15593 / 2712-8008 / 2020.4 .2$

Просьба ссылаться на эту статью в русскоязычных источниках следующим образом:

Южаков А.Л., Путилов И.С. Прогнозирование нефтегазоносности южной части Пермского края с использованием регионального трехмерного моделирования // Недропользование. - 2020. - Т.20, №4. - С.317-330. DOI: $10.15593 / 2712-8008 / 2020.4 .2$ 